Summer 2009

\title{
Shooting Blanks: The War on Tax Havens
}

Timothy V. Addison

Indiana University Maurer School of Law

Follow this and additional works at: https://www.repository.law.indiana.edu/ijgls

Part of the International Law Commons, and the Tax Law Commons

\section{Recommended Citation}

Addison, Timothy V. (2009) "Shooting Blanks: The War on Tax Havens," Indiana Journal of Global Legal Studies: Vol. 16 : Iss. 2 , Article 14.

Available at: https://www.repository.law.indiana.edu/ijgls/vol16/iss2/14

This Note is brought to you for free and open access by the Law School Journals at Digital Repository @ Maurer Law. It has been accepted for inclusion in Indiana Journal of Global Legal Studies by an authorized editor of Digital Repository@Maurer Law. For more information, please contactrvaughan@indiana.edu.

\section{$\Psi$}

JEROME HALL LAW LIBRARY

INDIANA UNIVERSITY

Maurer School of Law
Bloomington 


\title{
Shooting Blanks: The War on Tax Havens
}

\author{
Timothy V. Addison*
}

\begin{abstract}
The United States Treasury conservatively estimates that tax havens cost the United States over $\$ 100$ billion annually in lost tax revenue. In response to this epidemic, the United States and the Organization for Economic Cooperation and Development entered into Tax Information Exchange Agreements with states considered to be tax havens. These agreements received widespread recognition as a means of remedying this growing problem. These agreements, however, are largely symbolic and provide very few additional weapons to combat tax evasion enabled by tax havens. As evidence of this, the estimated annual loss of tax revenue due to tax havens has increased since the enactment of these agreements.

This Note argues that information exchange agreements are a reactionary policy and will neither truly eliminate nor curb tax evasion through tax haven states. To effectively combat the tax haven problem, policies must be adopted that should focus on domestic solutions and should strengthen existing laws that are far too weak and underutilized.
\end{abstract}

\section{INTRODUCTION}

"Half of the world trade appears to pass through tax havens, although they account for only $3 \%$ of the world's GDP."

* Executive Online Editor, Indiana Joumal of Global Legal Studies. J.D., 2009, Indiana University Maurer School of Law - Bloomington; B.A., 2006, University of Michigan-Ann Arbor. For all their support and encouragement, I thank my two brothers and my parents; without them, my accomplishments are nothing. Many thanks to Professor Leandra Lederman for her guidance and valuable feedback and to the staff of the Indiana Journal of Global Legal Studies. Any and all errors are mine, and mine alone.

1. Bruno Grutner, Tax Evasion: Hidden Billions for Development, Swiss Coalition of DeVELOPMENT OrGanizations (2004), http://unpanl.un.org/intradoc/groups/public/documents/apcity/ unpan018181.pdf.

Indiana Journal of Global Legal Studies Vol. 16 \#2 (Summer 2009)

CIndiana University Maurer School of Law - Bloomington 
This year alone, tax havens will cost the United States over $\$ 100$ billion in foregone tax revenue. ${ }^{2}$ I estimate that the present dollar value of the foregone tax revenue of the past decade is more than $\$ 1.027$ trillion. ${ }^{3}$ While governmental authorities tried to reduce this astronomical figure by crafting policies targeting tax havens, these attempts have generally been unsuccessful. This lack of success does not arise from a lack of effort; rather, such policies have been misdirected. Governments have prioritized the use of tax information exchange agreements, bilateral agreements, and multilateral agreements, yet these mechanisms do not actually address why tax havens exist. Without addressing why states choose to become tax havens, these tools are purely reactionary and will not eliminate the tax haven epidemic.

This Note examines previous attempts in which governmental authorities ${ }^{4}$ took action aimed at reducing tax evasion by curbing the use of offshore financial centers, more commonly termed "tax havens." Despite increasing the global awareness of tax havens' detrimental and disastrous effects upon global tax collection efforts, tax information exchange agreements have produced only minimal results and have not curbed the increasing, astronomically large tax gap that exists in the United States. For that reason, these agreements should be regarded as mostly symbolic in nature. Accordingly, this Note argues that a change in both domestic and international tax enforcement policies is required to reduce the type of tax evasion facilitated by the bank secrecy laws of tax havens.

Part I provides a basic analysis of what constitutes a tax haven, as well as an

2. See Staff of Perm. Subcomm. on Investigations, S. Comm. on Homeland Sec. and Governmental Affairs, hoth Cong., Tax Haven Banks and U.S. Compliance (Comm. Print 2008), available at http://hsgac.senate.gov/public/files/071708PSIReport.pdf [hereinafter TAx HaveN Banks and U.S. Compliance].

3. Using the 10 Year Treasury Note rate as of March 17, 2009, to determine the appropriate discount rate, over $\$ 1.027$ trillion has been lost to tax havens through transfer pricing schemes and individuals concealing income. I calculated this number using a future value table with a discount rate of $3.2 \%$. I chose to start with $\$ 70$ billion in 1999 because I felt that was a conservative estimate. I then increased each year by an incremental $\$ 5$ billion until I reached 2005 . From 2005 to 2008, I used $\$ 100$ billion based upon the findings in Joseph Guttentag \& Reuven Avi-Yonah, Closing the International Tax Gap, in Bridging the Tax Gap: Addressing the Crisis in Federal Tax Administration 101 (Max B. Sawicky ed., 2005). I believe that these numbers are conservative estimates, and I used this figure to merely demonstrate that over the past ten years, the amount of tax revenue lost to tax havens is quite substantial. See id.; see also Tax Haven Banks and U.S. Compliance, supra note 2, at 1.

4. While not an exhaustive list, the governmental organizations include the United States, the United Nations, the Organization for Economic Cooperation and Development (OECD), Financial Stability Forum (FSF), International Monetary Fund (IMF), and the European Union (EU). The non-governmental organizations include, but are not limited to, Oxfam, Christian Aid, and the Tax Justice Network. See Bill Maurer, Re-Regulating Offshore Finance?, 2 GEo. Compass 155, 155 (2008).

5. Id. at $155-56$. 
estimation of both domestic and worldwide losses in tax revenue caused by tax havens. Part II examines the characteristics of states that decide to engage in harmful tax competition. Empirical research suggests that only politically stable and sophisticatedly governed, developed states are able to promote tax evasion and thereby act as tax havens. Thus, it is inefficient for regulatory agencies to expend resources and craft policies that specifically target developing states that attempt to attract capital by enacting bank secrecy laws.

Part III analyzes the shortcomings of the previous attempts by the United States and the Organization for Economic and Cooperation Development (OECD) to successfully reduce and eliminate the total number of operating tax havens. Part IV examines the recent tax enforcement efforts targeting numerous individuals possessing bank accounts in Liechtenstein, the locus of recent tax evasion scandals.

Part V explores possible ways the United States and other governments could reduce the use of tax havens to shelter income and, accordingly, substantially reduce incentives that entice individuals to transfer capital to a tax haven. In doing so, this Note argues that because of the inherent problems in dealing with tax havens through collective action, governments would be best served by enacting harsher penalties and increasing audit levels that specifically target individuals and corporations that use tax havens to shelter income. Governments should enter into Tax Information Exchange Agreements (TIEAs) that become enforceable only when a certain number of tax havens enter into such agreements, thereby reducing a tax haven's incentive to hold out and not sign the agreement. Lastly, this Note argues that states must provide financial incentives to tax haven states to induce these states to adopt optimal tax policies that will maximize global welfare. These incentives are necessary to induce tax haven states to put the welfare of citizens of larger, wealthier nations above the welfare of their own citizens.

\section{The Effects of Tax Havens on Tax Revenues}

\section{A. What is a Tax Haven?}

No one can say with certainty what elements are required for a country to constitute a tax haven because no precise or exact definition exists. The OECD has developed a list of four key criteria that must be examined in order to determine whether a country should be classified as a tax haven. ${ }^{6}$ The criteria are: no or only

6. Org. for Econ. Cooperation and Dev., Harmful Tax Competition: An Emerging Global Issue (1998), available at http://www.oecd.org/dataoed/33/0/1904176.pdf [hereinafter OECD]. 
nominal taxes, ${ }^{7}$ a lack of effective exchange of information, ${ }^{8}$ a lack of transparency, ${ }^{9}$ and no substantial activity (for example, investments that are purely tax driven). ${ }^{10}$

In June 2002, the OECD identified thirty-five states as tax havens under these criteria. ${ }^{11}$ However, numerous additional criteria are commonly used to categorize a country as a tax haven, causing other lists to vary dramatically from the one compiled by the OECD. Simply stated, "[n]o two lists of tax havens look quite the same; the number of entries range anywhere from around twenty to almost one hundred jurisdictions." 2 This Note will therefore use the term tax haven simply to refer to any country that does not seek to attract real investment, but instead promotes tax evasion to attract and increase foreign capital held in its jurisdiction through the use of lenient tax laws and strict bank secrecy.

\section{B. Lost Tax Revenue in the United States}

On August 1, 2006, the U.S. Senate Committee on Homeland Security and Governmental Affairs released a report entitled Tax Haven Abuses: The Enablers, The Tools and Secrecy. ${ }^{13}$ To date, this is the most extensive report published by the Senate addressing concerns originating from the decreased tax revenues caused by tax havens. In the compilation of this report, the Permanent Subcommittee on Investigations spent over a year investigating and researching tax havens and how they operate. During that time, the Subcommittee issued over seventy-four subpoenas, conducted more than eighty interviews, and reviewed over two million pages of correspondence, electronic communications, and material in the public

\section{Id. $\ 52$.}

8. Id.

9. Id.

10. Id.

11. The thirty-five countries are as follows: Andorra, Anguilla, Antigua and Barbuda, Aruba, the Bahamas, Bahrain, Barbados, Belize, British Virgin Islands, Cook Islands, Dominica, Gibraltar, the Maldives, Marshall Islands, Monaco, Montserrat, Nauru, Netherlands Antilles, Niue, Panama, Samoa, Seychelles, St. Lucia, St. Kitts and Nevis, Grenada, Guernsey, Isle of Man, Jersey, Liberia, Liechtenstein, St. Vincent, the Grenadines, Tonga, Turks and Caicos, U.S. Virgin Islands, and Vanuatu. See OECD, 35 Jurisdictions Committed To Improving Transparency and Establishing Effective Exchange of Information on Tax Matters, http://www.oecd.org/document/19/0,2340,en_2649_ 37427_1903251_1_1_1_37427,00.html (last visited Mar. 28, 2009).

12. J.C. Sharman, Havens in a Storm 21 (2006).

13. See Staff of Perm. Subcomm. on Investigations, S. Comm. on Homeland Sec. and Governmental Affairs, iogrh Conc., Tax Haven Abuses: The Enablers, The Tools and Secrecy (Comm. Print 2006), available at http://levin.senate.gov/newsroom/supporting/2006/PSI.taxhavenabuses.080106.pdf. 
domain, consisting of legal pleadings, court documents, and Securities and Exchange Commission filings. ${ }^{14}$

The report concluded that offshore tax havens and secrecy jurisdictions hold over $\$ 11$ trillion of high-net-worth individuals' assets worldwide. ${ }^{15}$ Of that figure, it is estimated that U.S. citizens are responsible for over one trillion dollars offshore. ${ }^{16}$ As a result of offshore accounts, these individuals evade between $\$ 40$ to $\$ 70$ billion in U.S. taxes each year. ${ }^{17}$ If combined with the Internal Revenue Service (IRS) estimates of corporate tax evasion through the use of tax havens by corporations, the total estimated loss in tax revenue increases by over $\$ 30$ billion. $^{18}$ This figure would rise even more if the estimates included corporate use of offshore tax schemes such as transfer pricing ${ }^{19}$ and offshore tax shelters. ${ }^{20}$ In all, it is estimated that tax havens cost the United States between $\$ 123$ to $\$ 153$ billion in foregone tax revenue annually. ${ }^{21}$ Using this figure, the United States has lost over $\$ 1$ trillion in tax revenue in the last decade alone. This number grows to nearly $\$ 1.4$ trillion if the present time value of money is factored into the equation. As U.S. Senator Carl Levin said, “[w]ith a $\$ 345$ billion annual tax gap and a $\$ 248$ billion annual deficit, we cannot tolerate a $\$ 100$ billion drain on our Treasury each year from offshore tax abuses."22

\section{Worldwide Estimates of Lost Tax Revenue}

Although the foregone tax revenue is of considerable magnitude in the United States, it represents only a fraction of the global problem. As of March 2005, it is esti-

14. Id. at 4.

15. Id. at 1.

16. See Guttentag \& Avi-Yonah, supra note 3, 101 (estimating that approximately $\$ 1.5$ trillion is held offshore by U.S. residents).

17. See id.

18. Id.

19. Transfer pricing is the practice involving multinational corporations with many wholly owned subsidiary companies overcharging a subsidiary company in a high tax jurisdiction to reallocate money (profits) to a low tax jurisdiction.

20. See Guttentag \& Avi-Yonah, supra note 3.

21. See Simon J. Pak \& John S. Zdanowicz, U.S. Trade with the World: An Estimate of 2001 Lost U.S. Federal Income TAx Revenues Due to Over-Invoiced Imports and Under-Invoiced Exports (2002) (executive summary), available at http://dorgan.senate.gov/newsroom/extras/ pak-zdan.pdf.

22. Press Release, Office of United States Senator Carl Levin, Levin, Coleman, Obama Introduce Stop Tax Haven Abuse Act (Feb. 17, 2007) http://www.senate.gov/ levin/newsroom/release .cfm?id $=269479$. 
mated that over $\$ 255$ billion in tax revenue ${ }^{23}$ is lost worldwide on account of tax havens each year. ${ }^{24}$ In 1998, Merrill Lynch/Cap Gemini released a report estimating that one-third of all assets held by the world's high-net-worth individuals-individuals who have $\$ 1$ million or more of liquid financial assets-were located in offshore accounts. ${ }^{25}$ This amount is expected to increase by over $\$ 600$ billion during $2009 .^{26}$

Industrialized states are not the only states adversely affected by tax havens. "Developing countries are losing tax income of at least $\$ 15$ billion USD a year due to this tax evasion of their own rich elites." 27 Other estimates of lost revenue have been as high as $\$ 50$ billion. ${ }^{28}$ To put such a number in perspective, $\$ 50$ billion is equivalent to the amount of aid the OECD annually distributes to developing states. ${ }^{29}$ These lost tax revenues could help fund the creation of additional and necessary commercial infrastructures, improve the quality of education and healthcare systems, and provide funding for various other important public programs that would enhance the overall standard of living in developing states.

\section{Tax Havens Decrease Aggregate Social Welfare}

Economists generally believe that in almost all circumstances, free market competition between firms facilitates efficiency, innovation, and social welfare. In the tax sphere, each state can be analogized to a firm that has its own mixture of publicly provided goods that is paid for by either low or high taxes (infrastructure, education, and national defense, for example). Thus, every state should theoretically seek to maximize its citizens' own social welfare, and accordingly, enact tax codes that correspond to citizens' preferences as to the portfolio of public goods provided. ${ }^{30}$

23. See Tax Justice Network, Briefing Paper-The Price of Offshore (2005), http://www. taxjustice.net/cms/upload/pdf/Price_of_Offshore.pdf.

24. This estimate does not account for lower taxes rates in all other countries resulting from tax competition caused by tax havens.

25. See Tax Justice Network, supra note 23.

26. Id.

27. See Grutner, supra note 1 , at 25.

28. Oxfam International, Tax Havens: Releasing the Hidden Billions for Poverty Eradication, http://publications.oxfam.org.uk/oxfam/display.asp? K=20040623_2316_000034 (last visited on Feb. 10, 2008).

29. Grutner, supra note 1 , at 25.

30. In regard to countries enacting such policies, it is assumed that the country is democratic and the citizens will vote to enact laws that reflect their preferences. If the citizens disapprove of the laws enacted, they will relocate to a country where laws reflect their preferences-hence they will speak with their feet. Simply stated, they will move to a different country that provides the desired level of taxation and public goods to increase and maximize utility. 
Often cited in favor of tax havens, Charles Tiebout's famous proposition was that the citizens should "vote with their feet." ${ }^{\text {"I1 }}$ If an individual does not like the mixture of public goods provided by his government, that person will relocate to a different state. This should, in turn, promote efficiency by pressuring governments to use tax revenues to effectively and efficiently improve social welfare.

This theory has several problems. First, it ignores the fact that individuals are not completely mobile. ${ }^{32}$ Second, this theory was conceived in a time when states were not globally connected. In today's society, the free flow of capital and information allows people to keep their financial investments in one state while living halfway around the world. Thus without global governmental cooperation regarding taxation on capital, individuals can effectively have their cake and eat it too. "[T]he foreign investor may not pay enough tax to cover the cost of the public spending from which it benefits." ${ }^{33}$ And consequently, "The OECD seems on solid ground, therefore, in its assertion that tax havens generally detract from global welfare." ${ }^{34}$

To reduce the incentives and profitability of tax havens, states may react by lowering their own rate of tax on capital. Thus, tax havens also decrease tax rates in nonhaven states. Arguably, this may actually benefit industrialized states, as it should theoretically increase public demand to eliminate wasteful spending in an attempt to close the tax gap. If this form of competition did increase social welfare, it would indicate that taxes had been too high and that public goods were overproduced. However, this theory has not been substantiated by any conclusive study. ${ }^{35}$ On the other hand, the American public has been unwilling to significantly reduce its government's expenditure on public goods even with a federal budget deficit approaching $\$ 11$ trillion, which provides some evidence that the government's expenditure on public goods is not excessive. ${ }^{36}$

31. Charles Tiebout, A Pure Theory of Local Expenditures, 64 J. PoL. Econ. 416 (1956).

32. Additionally, this theory assumes that all countries are similar in size, resources, and development. If this was an appropriate assumption, then tax competition would probably maximize social welfare. That is, people would call for the most desirable mixture of public goods while also demanding that such goods are provided at minimal costs; thus wasteful spending presumably would not be tolerated. However, not all countries are similarly positioned in size, resources, and development. As a consequence, tax havens can effectively attract mobile capital without bearing any of the burdens that enable capital markets to produce positive returns.

33. Michael Littlewood, Tax Competition: Harmful to Whom?, 26 Мıсн. J. INT'L L. 411, 449 (2004).

34. Id. at 439.

35. See Joel Slemrod \& John D. Wilson, Tax Competition with Parasitic Tax Havens (Nat'l Bureau of Econ. Research, Working Paper No. 12225, 2006), available at http://www.nber.org/papers/wl2225.

36. See Treasury Direct, http://www.treasurydirect.gov/NP/BPDLogin?application =np (last visited Mar. 25, 2009). 
As explained above, non-tax haven states have been forced to alter their tax rates on mobile capital in an effort to divert the outflow of capital to tax havens. It becomes a race to the bottom as countries lower taxes to decrease the incentives of concealing income in a tax haven. While this reduces the demand for tax haven services, the aggregate amount of tax revenue in the non-tax haven state decreases. Correspondingly, the quantity of public goods is likewise reduced to a suboptimal level, thereby reducing the aggregate social welfare. ${ }^{37}$ Worse, vast resources must then be allocated to tax enforcement activities that target tax havens, which further reduces resources available for public programs, thereby decreasing social welfare. ${ }^{38}$ Thus, while "it is optimal for countries to devote resources to defend this revenue base," ${ }^{\prime 3}$ it is not a desirable allocation of human resources. In other words, the people devoted to enforcing tax collections are not actually producing goods because these collections should have occurred without their efforts. Perhaps even more problematic is that tax havens may actually undermine voluntary compliance because individuals and corporations do not wish to be the only "suckers" paying taxes. As the number of cheaters increases, so do the incentives for others to begin cheating and engaging in illegal tax evasion. ${ }^{40}$

\section{Incentives and Qualities Giving Rise to The Creation of Tax Haven States}

To determine what actions the United States and other states should take against tax havens, it is first necessary to examine the qualities that give rise to the creation of tax havens. By furthering this understanding, more effective policies may be crafted and implemented to specifically target tax evaders hiding behind bank secrecy laws in a tax haven.

\section{A. Incentives for a State to Become a Tax Haven}

Many states see benefits in either becoming a tax haven or in allying with tax havens by enacting bank secrecy laws that help wealthy individuals transfer their assets to tax havens. "Roughly 15 percent of countries are tax havens ... these

37. Slemrod \& Wilson, supra note 35 , at 21 .

38. Id.

39. Id. at 35.

40. See Danshera Cords, Tax Protestors and Penalties: Ensuring Perceived Fairness and Mitigating Systemic Costs, 2005 BYU L. Rev. 1515, 1570 (2005). 
countries tend to be small and affluent." ${ }^{, 41}$ And even with 15 percent of the world's states acting as tax havens, "[h]alf of the world trade appears to pass through tax havens, although they account for only $3 \%$ of the world's GDP.'42

A state becomes a tax haven for one undeniable reason: to attract capital to help promote growth in its financial industry. To put it more eloquently, "[t]ax haven countries receive extensive foreign investment, and, largely as a result, have enjoyed very rapid economic growth over the past 25 years. ${ }^{243}$ The reason lies in basic economics: lower tax rates increase investors' after-tax returns and thereby increase incentives to transfer assets in the form of investments from a high-tax to a low-tax jurisdiction. Tax havens are the ultimate low-tax jurisdictions, suggesting that tax havens experience the largest capital influx of investment. And that is precisely what statistical data has indicated.$^{44} \mathrm{~A} 10$ percent reduction in tax rates typically causes a 6 percent increase in inbound foreign investment. ${ }^{45}$ "There are only three sources of income to tax-land, labour, and capital —only one of them cannot flee. Capital can flee at the speed of light today ...."46

Yet in the past, many states have sought to counter such basic contentions. In doing so, states adversely affected by tax havens have commonly argued that such low tax rates cannot sustain necessary government operations. Also, they argue that individuals and corporations that evade taxes through tax havens use a disproportionate amount of government services in proportion to their paid taxes. That is, they get more from the government than what they give. Most states agree that, in addition to a reduction in their domestic social welfare, tax havens also decrease global social welfare. Nevertheless, states have ignored the reasons why other nations choose to become tax havens and have therefore failed to adopt strategies that account for why tax havens exist.

Countering such contentions, tax havens argue that their sovereignty should not be violated simply because they have different views on taxation. Tax havens are quick to point out that governments choose their own taxation policies and can scale back such government-provided benefits if need be. Tax havens argue that they have no need for high taxes on capital and instead can adequately collect

41. Dhammika Dharmapala \& James R. Hines, Which Countries Become Tax Havens 1 (NBER Working Paper No. 12802, 2006), available at http://www.nber.org/papers/w12802.

42. GrutNer, supra note 1 , at 24.

43. Dharmapala \& Hines, supra note 41 , at 1 .

44. Id. at 3 .

45. Id.

46. Terry Dwyer, "Harmful" Tax Competition and the Future of Offshore Financial Centres, Such as Vanuatu, PAc. Econ. Bull., 2000, at 48, 57. 
the necessary tax revenue from taxes on labor and land. Perhaps this is because havens tend to have small populations and are generally not welfare states. ${ }^{47}$ States that tend to become tax havens "are small countries, commonly below one million in population, and are generally more affluent than other countries." ${ }^{\prime 28}$ Additionally, "tax havens tend to have open economies (in that they are physically closer to major capital exporters, less likely to be landlocked, more likely to be islands, and have a larger proportion of their population living close to the coast). ${ }^{349}$ Finally, tax havens tend to have fewer available natural resources than other states. ${ }^{50}$

\section{B. Developing States Are Not Competitive with Tax Havens in the Financial Services Industry}

In order for a state to actually attract capital because of its taxation policies, its commitment and ability to provide such tax evasion services must be credible. If foreign depositors do not believe that the state will continue such policies, or believe that the government is unstable and cannot properly support a fluid financial industry, depositors wishing to conceal funds will go elsewhere. For an individual to remain undetectable by his state of residence, tax havens must have a historical record for high quality governance, a well-functioning financial industry, an established legal market, and banking secrecy laws. Without a strong track record, potential investors seeking tax havens will turn to alternatives in order to minimize risk and maximize return.

Additionally, states that become tax havens must have a very low level of governmental corruption. ${ }^{51}$ This can likely be explained by the fact that corruption creates an unpredictable government, thereby increasing the risk associated with holding financial assets in that state. Therefore, the overall expected gains will, on average, be less in a corrupt government than in a stable one. Poor governance also creates doubt about both the state's future economic well-being and the stability of its currency. Investors will choose a government that does not suffer from such deficiencies.

Thus, for a state to successfully market its tax-free financial services its government, banking laws, and economy must all be relatively stable and free from corruption and bribery. Such states must be able to provide the necessary public

47. Dharmapala \& Hines, supra note 41 , at 11 .

48. Id. at 1 .

49. Id. at 11 .

50. Id.

51. Id. at 13 . 
goods (infrastructure, schools, roads, etc.) by imposing taxes primarily upon sources that are difficult or impossible to move; specifically, land and labor. If public goods are not sufficient to provide for a stable government and economy, the state will quickly deteriorate. This would then increase the overall risk associated with maintaining financial assets in that state.

Even if a developing state could credibly commit to becoming a tax haven, it would most likely be unwise and disastrous for its future economic growth. Because of the fierce competition among other tax havens, many tax havens are "profitable" only by the thinnest of margins. ${ }^{52}$ Developing states cannot adequately provide their citizens with necessary public goods. The elimination of certain taxes would greatly diminish these states' already inadequate tax revenues, and therefore, their ability to further provide necessary public goods. Lastly, developing states enacting such tax policies would likely see a dramatic decrease in foreign government aid as a form of punishment. These consequences would further increase the risk associated with concealing income in a developing state, thereby decreasing the average total expected return.

\section{Shortcomings of Current and Past Efforts Attempting to Reduce the Total Number of Tax Havens in Existence}

[A]s a result of globalization and tax competition, countries that act unilaterally or by bilateral tax treaties can no longer set tax rules. In a world in which capital can move freely across national borders and [multinational enterprises] are free to choose from among many investment locations, the ability of any one country (or any two countries in cooperation) to tax (or otherwise regulate) such capital is severely limited. ${ }^{53}$

All tax havens derive a substantial portion of their gross domestic product from their financial industry. ${ }^{54}$ Past attempts to reduce the total number of tax

52. See Sharman, supra note 12, at 11.

53. Reuven S. Avi-Yonah, Globalization, Tax Competition, and the Fiscal Crisis of the Welfare State, 113 Harv. L. Rev. 1573, 1675 (2000) (proposing the creation of a withholding tax regime by developed nations to combat tax flight).

54. For example, it is estimated that the Cayman Islands derives $40 \%$ of its gross national product from its financial industry. See U.S. Dept. of State, Background Note: Cayman Islands, http:// www.state.gov/r/pa/ei/bgn/5286.htm (last visited Mar. 12, 2008). 
havens have ignored this truth. As a consequence, previous attempts to persuade a tax haven to change have failed.

\section{A. The OECD and Cooperation Agreements}

Beginning in 1998, with the publication of Harmful Tax Competition: An Emerging Global Issue, the OECD began a shame campaign against tax havens by attempting to draw attention to states that did not comply with its demands. The OECD announced that a future report would include all states it considered uncooperative tax havens. Initially, the OECD planned to list thirty-five states as tax havens. However, the OECD promised to remove any tax haven from the list if the tax haven pledged to reduce and eventually eliminate the policies the OECD considered harmful. ${ }^{55}$ In an attempt to force the uncooperative tax havens into compliance, the OECD recommended that other states take unilateral action against these tax haven states. These eleven recommendations included the following sanctions:

- To disallow deductions, exemptions, credits, or other allowances related to transactions with Uncooperative Tax Havens or to transactions taking advantage of their harmful tax practices.

- To require comprehensive information reporting rules for transactions involving Uncooperative Tax Havens or taking advantage of their harmful tax practices, supported by substantial penalties for inaccurate reporting or nonreporting of such transactions.

- For states that do not have controlled foreign corporation (CFC) or equivalent rules, to consider adopting such rules, and for states that have such rules, to ensure that they apply in a fashion consistent with the desirability of curbing harmful tax practices (Recommendation 1 of the 1998 Report).

- To deny any exceptions (e.g. reasonable cause) that may otherwise apply to the application of regular penalties in the case of transactions involving entities organized in Uncooperative Tax Havens or taking advantage of their harmful tax practices.

- To deny the availability of the foreign tax credit or the participation exemption with regard to distributions that are sourced from Uncooperative Tax Havens or to transactions taking advantage of their harmful tax practices.

- To impose withholding taxes on certain payments to residents of Uncooperative Tax Havens.

55. See OECD, supra note 6. 
- To enhance audit and enforcement activities with respect to Uncooperative Tax Havens and transactions taking advantage of their harmful tax practices.

- To ensure that any existing and new domestic defensive measures against harmful tax practices are also applicable to transactions with Uncooperative Tax Havens and to transactions taking advantage of their harmful tax practices.

- Not to enter into any comprehensive income tax conventions with Uncooperative Tax Havens, and to consider terminating any such existing conventions unless certain conditions are met (Recommendation 12 of the 1998 Report).

- To deny deductions and cost recovery, to the extent otherwise allowable, for fees and expenses incurred in establishing or acquiring entities incorporated in Uncooperative Tax Havens.

- To impose "transactional" charges or levies on certain transactions involving Uncooperative Tax Havens. ${ }^{56}$

These commitments proved ineffective at reducing harmful tax practices. In retrospect, this is not particularly surprising. Because of inadequate governmental enforcement efforts, most of these suggested sanctions relied upon the tax havenseeking individual to voluntarily inform the appropriate government agency. If that person is indeed attempting to evade taxes, it is highly improbable that he would voluntarily notify the proper authorities of his transactions with the uncooperative country. Thus, if these states were in fact being used to evade taxes, many of the OECD's penalties arguably would do nothing. For this reason, a majority of tax havens quickly pledged to help stop tax evasion in an attempt to silence global outcry and criticism without really having to change. The OECD's cooperation pledges did not require tax havens to take any immediate or decisive action. ${ }^{57}$ Instead, these pledges required only symbolic statements on behalf of the tax havens.

Without actually providing economic incentives to compensate the tax havens for decreases in their overall welfare ${ }^{58}$ and gross domestic products derived from the tax haven international finance industry, cooperating with tax-enforce-

56. OECD, Towards Global. TAx Co-operation 25 (2000), available at http://www.oed.org/ dataoecd/9/61/2090192.pdf.

57. Steven A. Dean, Philosopher Kings and International Tax: A New Approach to Tax Havens, Tax Flight, and International Tax Cooperation, 58 Hastincs L.J. 911, 961 (2007).

58. The tax revenue referred to here is derived from taxes on increased value of the land and the additional labor needed to operate the financial industry. 
ment agencies simply does not make business sense for tax havens. The tax havens vowed to cooperate, but promised their financial industries that their pledged cooperation commitments would not fundamentally alter any tax and bank secrecy laws. To accomplish this, tax havens publicly declared that any future agreements or treaties entered into would not require them to relinquish any financial records unless certain stringent conditions were satisfied.

Perhaps more problematic from a fairness perspective, the OECD's initiative only placed demands on non-OECD members while member states possessing certain attributes common to tax havens were not obligated to alter their tax laws. ${ }^{59}$ As Senator Carl Levin stated in The Economist in 2002 while discussing certain tax practices deemed "harmful" by the OECD, "[w]e are basically doing the same thing." ${ }^{" 00}$ As a result of such internal disputes and a lack of a consensus, key member states, including the United States, withdrew their support and the cooperation commitment agreement with tax havens systematically fell apart.

While the OECD's cooperation commitment initiative did raise global awareness, it did little to reduce tax evasion and the use of tax havens. The OECD readily acknowledges that tax havens have not disappeared and are a continuing and growing threat to the tax revenues of all states. ${ }^{61}$ Yet, as of April 2008, only Andorra, Liechtenstein, and Monaco remained on the list of uncooperative tax havens. ${ }^{62}$ Ultimately the failure of the cooperation commitments stems from the lack of incentives given to cooperative tax havens. These failed commitments simply fostered an environment of "double talk." And, as expected, overall cooperation was minimal. ${ }^{63}$ Only in recent months have some OECD member states expressed dissatisfaction and impatience with "the overall level of cooperation seen by states once targeted by the ongoing tax havens initiative." ${ }^{64}$

59. See Sharman, supra note 12, at 75 .

60. Shell Game, Economist, Oct. 26, 2002, at 99 (discussing how most states do not require corporate ownership information at the time of formation).

61. Press Release, OECD, Fighting Offshore Tax Evasion (Feb. 26, 2008) http://www.viewontv .com/oecd/250208_tax-evasion-and-tax-havens/index.php.

62. Press Release, OECD, OECD removes the Marshall Islands from its List of Un-cooperative Tax Havens (Aug. 7, 2007) http://www.oecd.org/document/13/0,3343,en_2649_201185_39095565_1 _1_1_1,00.html; see also OECD, List of Uncooperative Tax Havens, http://www.oecd.org/documen t/57/0,3343,en_2649_201185_30578809_1_1_1_1,00.html (last visited Mar. 28, 2009).

63. Lawrence J. Speer, OECD Seeks More Global Cooperation on Tax Havens, Italian Tax Official Says, Daily TAx Rep. (BNA), Mar. 3, 2008, at I-1.

64. Id. 
B. The United States, OECD, and Tax Information Exchange Agreements: Catch-22?

While cooperation commitments did not lead to any noticeable reduction in the tax gap attributable to tax havens, they did foster an environment of smoke and mirrors, specifically the adoption of TIEAs. While many variations of such agreements exist, a TIEA typically has three specific qualities. ${ }^{65}$

To begin with, a TIEA must provide for the exchange of information on requests for both criminal and civil tax matters. It must also provide for the exchange of information even if such information relates to a person who is not a resident or national of the United States or the TIEA partner. Finally, it must provide for the disclosure of information regardless of local confidentiality laws that may prohibit such disclosure, including laws relating to bank secrecy or bearer shares. ${ }^{66}$

Over the past decade, the United States has entered into fourteen ${ }^{67}$ TIEAs with states initially classified as tax havens by the OECD. ${ }^{68}$ However, these agreements only ensure that the participating country will relinquish the requested information so long as the United States is able to present evidence linking the suspected individual's bank accounts to either tax evasion or criminal activity, primarily money laundering. That is, the United States has to prove that the request is not merely a "fishing expedition." ${ }^{\prime 69}$

Consequently, without granting governmental authorities access to all financial records necessary to determine if any of their citizens are using the tax haven to conceal income, governments must first discover which citizens actually maintained bank accounts and other financial devices used to conceal income in that

65. Press Release, Testimony of Treasury Acting International Tax Counsel John Harrington before the Senate Finance Committee on Offshore Tax Evasion (May 3, 2007) http://www.ustreas. gov/press/releases/hp385.htm.

66. Id.

67. This includes Antigua and Barbuda, Aruba, the Bahamas, Barbados, Bermuda, British Virgin Islands, Cayman Islands, Costa Rica, Dominica, Grenada, Guernsey, Isle of Man, Jersey, and the Netherlands Antilles. David Spencer \& J.C. Sharman, International Tax Cooperation (Part 2), 19 J. Int'L TAx'N 26, 34; see also U.S. Gov't Accountability Office [GAO], Rep. No. GAO-09-I57, INternational Taxation: Large U.S. Corporations and Federal Contractors with Subsidiaries in Jurisdictions Listed as Tax Havens or Financial Privacy Jurisdictions (2008).

68. In addition to these fourteen TIEAs, the United States has also entered into double tax treaties with an exchange of information provision with five countries considered tax havens. Of these five countries, one has entered into both the double tax treaty with an exchange of information provision and a TIEA. See also GAO, supra note 67, at 12-13.

69. Amanda Banks, US Tax Pact Does Not Herald "Open Season" In the Caymans, Say Officials, TAX News.Com, Dec. 10, 2001, http://www.tax-news.com/archive/story/US_Tax_Pact_Does_ Not_Herald_Open_Season_In_The_Caymans_Say_Officials_xxxx6614.html. 
particular tax haven. The proof requirements render these commitments circular. Tax havens only cooperate with investigations when presented with evidence of wrongdoing. Without a tax haven's cooperation, however, such evidence is usually unavailable and nearly impossible to obtain. In sum, these agreements have produced a "Catch-22."70

Tax havens ultimately are not required to help a foreign government identify previously unknown tax evaders, which is where most of the help is needed. Worse yet, it has been strongly suggested that most TIEAs do not "override bank secrecy provision[s] in the tax haven laws." 71 Thus, "existing tax information exchange agreements, while helpful and important in some cases, are of limited value in closing the overall international tax gap." 72

TIEAs will continue to be ineffective if the United States and other OECD member states do not enact more effective legislation to combat tax evasion and provide adequate incentives for tax havens to seek out tax evaders. Even if such agreements did actually achieve their objectives and were cause for concern for a tax evader, the rational tax evader would simply shift his financial assets to a noncooperating tax haven that has yet to enter into a TIEA. ${ }^{73}$ This will shift business to non-cooperating tax havens. A tax haven will strengthen its bargaining position in any future negotiation with states that are seeking to change the tax haven state's laws or are simply attempting to obtain information about certain individuals using a TIEA. Because of this increased activity in a tax haven's financial industry, the tax haven will now require greater compensation before it will alter or

70. See Joseph Heller, Catch-22 (Simon and Schuster 1999) (1959).

There was only one catch and that was Catch-22, which specified that a concern for one's safety in the face of dangers that were real and immediate was the process of a rational mind. Orr was crazy and could be grounded. All he had to do was ask; and as soon as he did, he would no longer be crazy and would have to fly more missions. Orr would be crazy to fly more missions and sane if he didn't, but if he was sane he had to fly them. If he flew them he was crazy and didn't have to; but if he didn't want to he was sane and had to. Yossarian was moved very deeply by the absolute simplicity of this clause of Catch-22 and let out a respectful whistle. "That's some catch, that Catch-22," Yossarian observed. "It's the best there is," Doc Daneeka agreed.

Id. at 55 .

71. See Testimony of Reuven S. Avi-Yonah Before the Senate Finance Committee on Offshore Tax Evasion, 110th Cong. (May 3, 2007), available at http://www.senate.gov/ finance/hearings/ testimony/2007test/050307testra-y.pdf.

72. Id.

73. Id. 
relinquish its parasitic tax and banking laws. Eliminating only one tax haven without affecting all other tax havens will produce little, if any, noticeable results. "This is a global problem, so there can only be a global solution."74

\section{Tax Havens Are Experiencing a Growth in Their Financial Industries Despite Current Efforts}

The OECD contends that "most countries have made considerable progress in implementing the transparency and exchange of information standards that the Global Forum wishes to see achieved." ${ }^{\text {"I }}$ If this were true, estimates of lost tax revenue on account of tax havens would presumably have decreased in percentage over the last several years. Yet, it is estimated that tax havens annually cost over $\$ 255$ billion in tax revenue, and this number is only expected to grow in the future. ${ }^{76}$

For example, the Cayman Islands is considered a cooperative tax haven and was never actually put on the OECD's list. ${ }^{77}$ Evidencing the Cayman Islands' commitment to the OECD, it entered into a TIEA with the United States in 2001. ${ }^{78}$ This agreement became effective with respect to criminal matters on January 1 , 2004, while all provisions relating to civil tax matters became effective on January 1 , $2005 .{ }^{79}$ However, it was duly noted that information would only be provided to the United States if a proper request was made pursuant to all of the treaty provisions, which require that the requesting agency first make a prima facie case. ${ }^{80}$

In light of this agreement, the Cayman Islands has experienced stable growth in its financial industry and has maintained its global position as the fifth largest international banking center with respect to liabilities, and the sixth largest with

74. Speer, supra note 63.

75. See Press Release, OECD, OECD Welcomes Tax Information Exchange Agreement Between Antigua and Barbuda and Australia (Feb. 2, 2007), http://www.oecd.org/document/26/0,2340,en_26 49_201185_38044186_1_1_1_1,00.html; see also OECD, TAx Co-operation: Towards a Level PlayING FiELD (2007), http://www.bfsb-bahamas.com/news_photo/Tax\%20Cooperation_OECD.pdf.

76. TAX Justice Network, supra note 23.

77. OECD, The OECD's Project on Harmful Tax Practices: The 200i Progress Report (2001), available at http://www.oecd.org/dataoecd/60/28/2664438.pdf.

78. Press Release, U.S. Dept. of Treas., PO-823 (Nov. 27, 2001) http://www.treas.gov/press/releases/po823.htm (last visited Feb. 10, 2008).

79. Cayman Islands: Money Laundering Initiatives, Mondaq Bus. Briefing, (Jan. 19, 2001), available at 2001 WLNR 7517475.

80. Cayman Islands: The Cayman Islands - Thriving Amid the OECD FAFT and Other International Initiatives, Mondaq Bus. Briefing, (Feb. 9, 2001), available at 2001 WLNR 7542158. This type of provision, however, is typical of all tax information exchange agreements currently in force with the United States. 
respect to total assets held in its jurisdiction. ${ }^{81}$ The Cayman Islands even reported a growth of over $\$ 400$ billion in its financial industry's external assets and liabilities. In fact, the Cayman Islands is currently ranked fourth in market share for international banking, behind only the United Kingdom, the United States, and France. ${ }^{82}$

While it may be argued that this growth is due to other factors, the Cayman Islands is not in an ideal geographic location for international banking. It does not possess any large financial stock exchange, large cities, or any other attributes commonly held by the world's large financial centers, such as New York City or London. The Cayman Islands has one major airport and is located thousands of miles away from any major financial center ${ }^{83}$ And not surprisingly, the Cayman Islands has a population of fewer than 50,000 people. ${ }^{84}$

Ultimately, the Cayman Islands, as well as other similarly situated tax havens, do not possess any comparative advantage in financial services. So why would such tax havens experience increased growth in their financial industries if they effectively gave up their favorable banking and tax laws? The answer is simple: the Cayman Islands did not radically change its favorable taxation policies or remove the veil of secrecy. The country still caters to individuals and corporations wishing to shift capital and conceal income. If this were not true, taxpayers would deposit their capital elsewhere, most likely in a bank near their domicile.

While TIEAs give government authorities a very useful tool in ascertaining the identities of individuals concealing income in tax havens, more must be done. In fact, in 2007 the IRS audited only 1.03 percent of all income tax returns in the United States. ${ }^{85}$ Worse, less than half of these audits were field audits. ${ }^{86} \mathrm{~W}$ ith such low audit rates it seems unlikely that exchange agreements actually deter individuals from concealing assets and income in a tax haven. Accordingly, without greater assistance from tax havens, which is very doubtful, domestic policies targeting tax havens must be vigorously pursued. Unilateral action will undoubtedly be much easier to enact

81. Cayman Islands Monetary Auth., Annual Report: i July 2006-30 June 2007 (2007), available at http://www.cimoney.com.ky/section/default.aspx? section = PUB\&id $=344$.

82. See Bank of Int'l Settlements, BIS Quarterly Review: International Banking and FiNancial Market Developments (2007), available at http://www.bis.org/publ/qtrpdf/r_qt0712.pdf.

83. See Central Intelligence Agency, The World Factbook-Cayman Islands, available at https://www.cia.gov/library/publications/the-world-factbook/geos/cj.html (last visited Feb. 11, 2008). 84. Id.

85. See Internal Revenue Service [IRS], Fiscal Year 2007 IRS Enforcement and Service Statistics (2007), http://www.irs.gov/newsroom/article/0, id $=177701,00$ html. I arrived at $1.03 \%$ by dividing the total number of income tax returns audited $(1,384,563)$ by the total number of tax returns filed $(134,421,400)$.

86. Id. 
and enforce, since the government would not rely upon the tax haven to take any action. Thus, states should take note and first pick the low-hanging fruit by optimizing domestic policies and enacting harsher penalties for tax evasion prior to attempting to force tax havens to radically change their tax policies and bank secrecy laws.

\section{The Lichtenstein Affair}

In February 2008, German investigators paid $\$ 7.4$ million to an informant for a list of 1,400 individuals of various nationalities who maintained bank accounts in Lichtenstein. German officials stated that they would distribute the names of these individuals to their corresponding states of domicile. While simply maintaining a bank account in Lichtenstein is perfectly legal, Lichtenstein's bank secrecy rules and its refusal to exchange information with other states foster an environment that attracts tax evaders. Although the individuals on the list have not necessarily engaged in tax evasion or illegal activity, being on this list has and will continue to draw attention and subsequent investigations by tax collection agencies.

\section{A. Would a Tax Information Exchange Agreement Have Made Any Difference in Combating Tax Evasion Schemes in Lichtenstein?}

The OECD lists Lichtenstein as a non-cooperative tax haven. But what if Lichtenstein had entered into tax information exchange agreements with all OECD member states? Would this have made any substantial difference? The answer is yes and no.

Even if there were such agreements, Lichtenstein would probably still have very lenient tax laws. Like the Cayman Islands, Lichtenstein is a very small nation with few exports. Nevertheless, unlike the Cayman Islands, Lichtenstein has virtually no other industries besides its self-created financial industry. Thus, Lichtenstein has far more to lose if it were to relinquish its tax and bank secrecy laws. As a best-case scenario for OECD member states, any TIEAs with Lichtenstein would mirror the agreement in place between the Cayman Islands and the United States. ${ }^{87}$ Therefore, it is unlikely that the results would drastically differ from those observed in the Cayman Islands.

If for some reason the results did in fact vary, and the TIEA did prove effective at identifying tax evasion, Lichtenstein's financial industry would lose a sub-

87. As previously noted, the Cayman Islands has not suffered any severe financial ramifications from the enactment of the tax information exchange agreements with OECD member countries. 
stantial number of financial accounts and assets as high-net-worth individuals would simply transfer their money to other non-cooperative tax havens. Thus, if the TIEA did in fact deter tax evaders from setting up accounts in Lichtenstein, the enforcement efforts would cause Lichtenstein's former clientele to move to other non-cooperative tax havens.

If TIEAs were not effective at identifying tax evaders, as the TIEA between the United States and the Cayman Islands seem to indicate, German officials would still have had to employ the same tactics used to obtain the list of possible tax evaders. Presumably, Germany and other governments did not know the identities of the individuals possessing accounts in Lichtenstein prior to purchasing the list from the informant. Otherwise, it seems that these individuals' financial records and lifestyles would have already been heavily scrutinized in an attempt to prosecute any tax evasion. Without first knowing the identities of such individuals, TIEAs are of no help. Accordingly, actions currently being taken by Germany, the United States, and other states with citizens identified on the list would have still been necessary.

Unless Germany could have first identified the individuals found on the list without the help of Lichtenstein, any such tax information agreement would have produced haphazard results and therefore would have been ineffective. Worldrenowned tax professor Reuven Avi-Yonah even stated before the Senate Finance Committee that many of these tax information agreements "typically require the U.S. to make a specific request relating to particular individuals, and they also typically do not override bank secrecy provisions in tax haven laws. ${ }^{188}$

\section{B. Lessons to be Learned from the Lichtenstein Affair}

As this Note has argued, while TIEAs may at times be helpful at combating tax evasion, these agreements are not the means to the end. Instead, intense investigations using purchased information and informants are highly effective at identifying both specific evasion tactics and individuals sheltering income in a tax haven. The Lichtenstein investigations highlight the importance of this kind of unilateral action. Moreover, they demonstrate that unilateral action may, at times, be far more effective at reducing the tax gap than negotiating for ineffective treaties and exchange agreements. Ultimately, until tax havens permit automatic disclosure of the tax information of those individuals earning income in their jurisdiction, the only truly effective and viable option to deter tax evasion and re-

88. See Testimony of Reuven S. Avi-Yonah, supra note 71. 
duce the tax gap must occur on the domestic front. The "Lichtenstein Affair" precisely demonstrates this truth.

\section{A Call for New Tactics Against Tax Havens}

While previous tactics have been touted as successful in combating the problems tax havens create, these very policies have not produced any significant results in dealing with tax havens. An alternative approach must be undertaken.

\section{A. Providing Financial Incentives to Tax Havens}

It has been argued that by using TIEAs, states adversely affected by tax havens could simply purchase the information necessary to collect the taxes. However, as more states enter these agreements, tax evaders fearful of being caught will simply shift their assets to non-cooperating tax havens. If the availability of tax haven services does not result in a reduced demand for such services, the only effect will be an increase in profitability. This scenario would decrease the total quantity of services provided by all tax havens by effectively pricing some wouldbe tax evaders out of the market. Thus, such agreements will actually move a competitive tax evasion market toward a monopolistic market, wherein it will be nearly impossible to force change. Consequently, without substantially reducing the total number of-or ideally eliminating-existing tax havens, TIEAs will only provide benefits for a very short period of time until the tax evaders transfer their assets to other non-cooperative tax havens. ${ }^{89}$

To remedy this problem, the interests of tax havens and non-tax haven states must be aligned. To accomplish this, non-tax haven states must provide financial incentives for participation in tax exchange agreements that offset the expected losses in gross national product in the tax haven. Non-tax haven states must give a monetary sum that is equal to or slightly greater than the expected revenues tax havens generate from their financial industries to secure their participation. ${ }^{90}$ To prevent tax havens from holding out in an attempt to receive a greater buyout, the official ratification of TIEAs must be contingent upon a fixed minimum number of tax havens entering

89. As of this time, the OECD has reported that over one hundred TIEAs are in force between the OECD member countries and non-OECD member countries. See OECD, supra note 6.

90. Unfortunately, no research or empirical studies have determined the amount of money that would be needed in order to buy off tax havens. Thus, this Note assumes that the uncollected tax revenues are greater than the overall profits generated by the tax haven's financial industry. 
into the agreement. This fixed number requirement will counteract the inherent holdout problem and prevent financial assets from being shifted from tax haven to another as more tax havens participate in the agreement. However, this solution will only achieve noticeable results if all, or nearly all, tax havens agree to it.

Full participation is not necessary because of the added benefits of reducing the total number of tax havens to a very small number. Government agencies will be able to specifically focus their enforcement efforts on the small number of tax havens that refuse to enter into such agreements. States will have more effective domestic enforcement against tax evaders, which will further reduce the incentives and benefits of shifting funds to a tax haven. Second, "if some, but not all, tax havens are eliminated, then countries are affected by the reduction in the supply of concealment services, because the equilibrium price of these services will increase." ${ }^{11}$ Further, if enough tax havens were eliminated, tax havens may enter into an oligopolistic form of competition..$^{92}$ Accordingly, concealment prices would further increase. ${ }^{93}$ Uncooperative tax havens should do this because the remaining states will now be in an oligopoly form of competition, thereby enabling these states to charge closer to monopoly pricing for these services to maximize revenue. In doing so, some tax evaders will be priced out of the market.

Therefore, because all states will either be economically better off or not worse off once the agreements are implemented, tax havens that initially support the TIEAs will logically help to persuade other tax havens to join. ${ }^{94}$ Likewise, all TIEAs entered into under this regime must have mandatory penalties to prevent

91. Slemrod, supra note 35, at 24.

92. In the oligopoly model, there are only a limited amount of firms. Each firm realizes that it, along with the other competing firms, can influence price and quantity of the good (for purposes of this Note, the good would be concealment services provided by tax havens). With a reduction in the number of firms in the market, each firm will have greater influence on the aggregate quantity of goods provided and the market price of the goods. This theory assumes that "the firms [for purposes of this Note, the firms would be the tax havens] are rational. They pursue well-defined goals, principally profit maximization. The second basic assumption is that firms apply their rationality to the process of reasoning strategically." Lynne Pepall et al., Industrial Organization: Contemporary Theory and Practice 198 (3d ed. 2005).

93. To increase prices, uncooperative tax havens may theoretically impose some sort of regulatory fees on foreigners transferring funds to their state to maximize total governmental revenues. Or, the financial sectors of the tax havens may raise prices to increase their operation profits. Regardless of whether the tax haven's government of private financial sector benefits from the decreased supply of concealment services and increased prices, prices should increase because of the reduced competition.

94. I assume that a country will always choose to participate in any agreement so long as the agreement either leaves the country in an identical position prior to the agreement or only nominally better off. 
states from shirking their responsibilities. ${ }^{95}$ Finally, these agreements must endure long into the future. They cannot be terminated with only a six-month notice period, as most active TIEAs permit. ${ }^{96}$

Ultimately, non-tax haven states would pay tax havens to reduce the nuisance. ${ }^{97}$ However, once again, "[f]or tax flight treaties to work, it must be sufficient that they would make everyone else (excluding tax cheats) better off." 98 While there is an open debate as to whether the increased tax revenue would be adequate to offset the tax haven's losses and still make everyone better off, if governments wish to acquire the services of tax havens in tracking down their customers, some type of financial incentive must be provided. Moreover, individuals utilizing tax haven services in order to evade taxes cannot be permitted to simply shift assets to other non-cooperative tax havens. Otherwise, such an agreement would prove completely ineffective.

Solely relying upon a TIEA to eliminate tax havens and recoup lost tax revenue will be insufficient. Accordingly, domestic policies must be employed to a much greater extent.

\section{B. Domestic Policies Must Be Fully Utilized}

Even if TIEAs were effective at gaining access to the necessary information to identify tax evaders, such agreements still would not produce results if the tax collecting agencies failed to enforce their own laws. Without audits, a TIEA will not be effectively utilized and will ultimately prove meaningless. As noted above, in the United States 1.03 percent of all federal income tax returns are audited.99 While the IRS audited almost 9.25 percent $^{100}$ of all individual tax returns with incomes over $\$ 1$ million in 2007 , only 2.26 percent ${ }^{101}$ of those with incomes above $\$ 200,000$ and less than $\$ 1$ million were audited. This leaves a combined aggregate total of 3,942,702 individuals with incomes over $\$ 200,000$ whose returns were not audited. ${ }^{102}$ To put that figure in context, there were an estimated 9.3 million indi-

95. See OECD, supra note 6.

96. See id.

97. Dean, supra note 57 , at 965.

98. Id.

99. See IRS, supra note 85.

100. The IRS audited 31,382 returns of 339,138 returns over $\$ 1$ million. Id.

101. The IRS audited 81,723 of $3,603,564$ tax returns with incomes between $\$ 200,000$ and $\$ 1$ million. Id. 102. Id. 
viduals with a net worth over $\$ 1$ million living in the United States as of the middle of 2007. ${ }^{103}$ As the Permanent Subcommittee on Investigations found, highnet-worth individuals, considered to have $\$ 1$ million or more in assets, currently hold $\$ 11$ trillion in offshore accounts. ${ }^{104}$ No matter how many TIEAs are in force, without a dramatic increase in the number of audits of high-net-worth individuals, such agreements will go underutilized and prove ineffective at curbing the concealment of income in offshore financial centers.

In addition to increasing audit rates for high-net-worth individuals, the IRS must be able to levy much higher penalties against individuals sheltering income in offshore financial centers. Most troubling, knowingly and willfully underpaying the amount of income taxes owed only results in a maximum 75 percent penalty on top of the amount due. ${ }^{105}$ While doubling the penalty to 150 percent has been proposed, such a penalty would still be insufficient to deter most tax evasion at the current audit levels. ${ }^{106} \mathrm{~W}$ ith such a low audit rate, penalties must be significantly higher to make risk-averse individuals refrain from concealing income in tax havens. ${ }^{107}$ Therefore, increasing the mandatory penalties and the number of audits conducted annually should have a considerable effect on the number of individuals contemplating tax evasion through the use of tax havens.

However, even increasing the audit rate may prove ineffective because the high-net-worth individuals who engage in tax evasion are very sophisticated and have presumably secured consultants who ensure that they have minimized all risks. Thus, harsher penalties must also be enacted and imposed upon individuals that promote and aid others in tax evasion.

103. TNS Reports Record Breaking Number of Millionaires in the USA, PRNEwswire, May 1. 2007, http://sev.prnewswire.com/banking-financial-services/20070501/AQTU05201052007-1.html.

104. See Staff of Perm. Subcomm. on Investigations, supra note 13.

105. IRC § 6663(a).

106. Press Release, Office of United States Senator Carl Levin, Levin, Coleman, Obama Introduce Stop Tax Haven Abuse Act (Feb. 17, 2007), http://levin.senate.gov/newsroom/release.cfm? id =269479.

107. Using basic game theory, if an individual will save $\$ 100,000$ from sheltering income, with a chance of being audited of $2.87 \%$, the penalty must be 46 times greater than the statutory penalty to deter tax evasion. The current statutory penalty is set at a maximum of $75 \%$. This example uses a $2.87 \%$ audit rate which is taken from the number of audits performed on individuals earning over $\$ 200,000$. Additionally, this example does not account for other costs that are not easily observable, such as embarrassment, imprisonment, and scorn. The formula for the calculation is as follows: $\$ 100,000$ (expected gain of not paying taxes) $=2.87 \%$ (audit rate) multiplied by (penalty $X+\$ 100,000$ owed in taxes). 


\section{Conclusion}

This Note has argued that additional unilateral and multilateral action must be taken to combat tax havens. The United States, the OECD, and all other states that are adversely affected by tax havens must unite through collective action and provide economic incentives to tax havens to relinquish their bank secrecy laws and to enact automatic TIEAs or withholding policies. By reducing the number of jurisdictions that maintain strict bank secrecy, the effective price for tax evasion services will accordingly rise, thereby effectively pricing some would-be tax evaders out of the market. To prevent the shifting of assets from one tax haven to another, this Note has proposed making the enforcement of TIEAs contingent upon a certain amount of participation and ratification from a predetermined number of operating tax havens. In doing so, the hold-out problem should be ameliorated, thus making all tax havens more willing to enter into these agreements. Furthermore, to help secure additional participation and support from tax havens, states should be willing to provide some type of compensation for cooperating tax havens. However, without first enacting domestic policy that exhausts all current, economically feasible unilateral actions, it is hypocritical to force smaller nations to take greater actions that have severe ramifications on their economies.

The past ways of unilaterally dealing with individual tax havens are no longer suitable in a global economy. The United States and the OECD will fail to counter the undesirable effects tax havens have upon tax revenue until they stop relying upon their overall economic dominance and power. Instead, the United States and the OECD must use an approach that is beneficial for all parties involved, especially tax havens. 


\section{Indiana University Press/Journals}

\section{Transactions}

\section{A Quarterly Journal in American Philosophy}

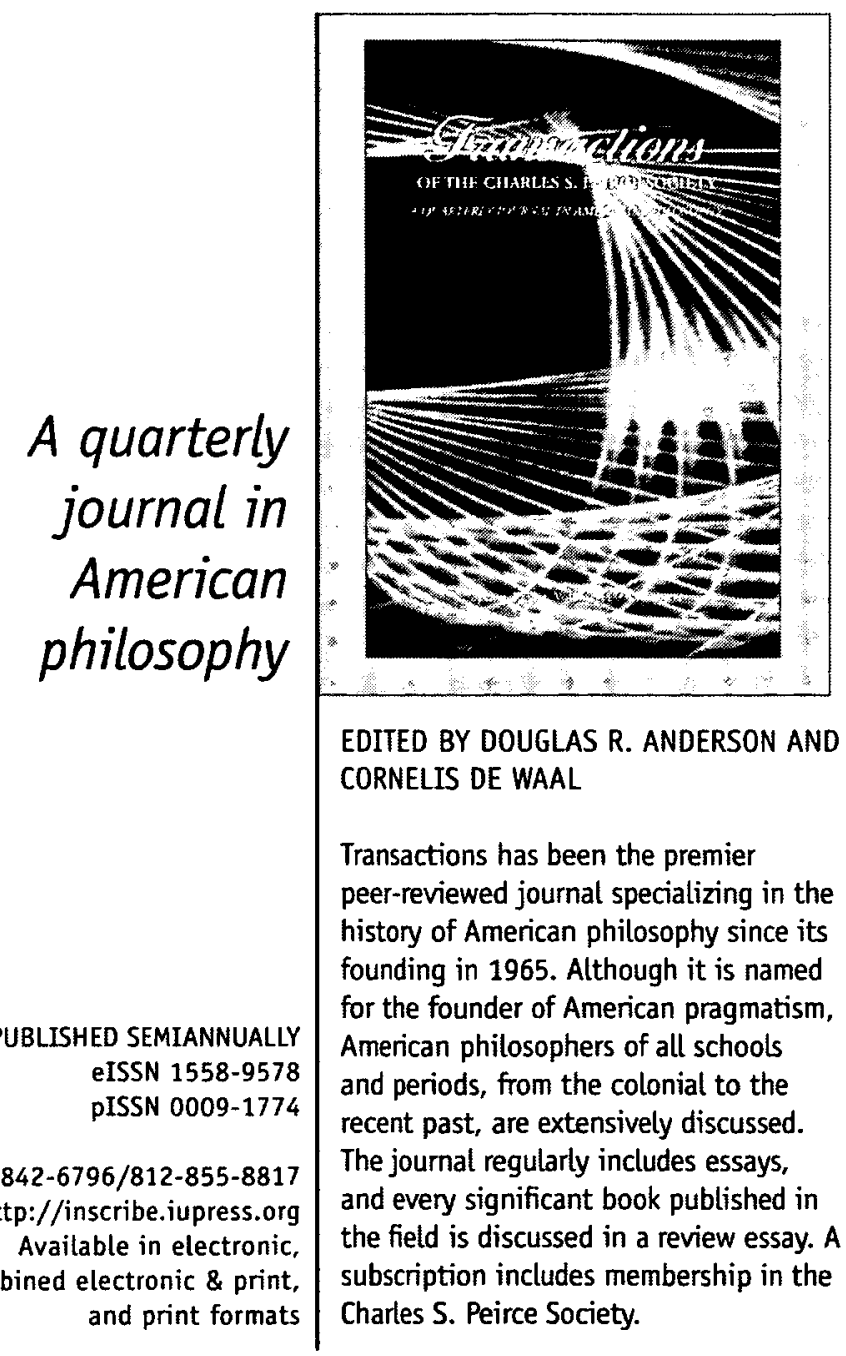

800-842-6796/812-855-8817

http://inscribe.iupress.org

Available in electronic, combined electronic \& print, and print formats

EDITED BY DOUGLAS R. ANDERSON AND CORNELIS DE WAAL

Transactions has been the premier peer-reviewed journal specializing in the history of American philosophy since its founding in 1965. Although it is named for the founder of American pragmatism, American philosophers of all schools and periods, from the colonial to the recent past, are extensively discussed. The journal regularly includes essays, and every significant book published in the field is discussed in a review essay. $A$ subscription includes membership in the Charles S. Peirce Society.

\section{TI $\mid \begin{aligned} & \text { INDIANA UNIVERSITY PRESS } \\ & \text { INDIANA UNIVESITY }\end{aligned}$}

601 North Morton Street, Bloomington, Indiana 47404-3797 USA 